\title{
Carbon Footprint Accounting and Low-Carbon Path Optimization for Imported Timber-based Wooden Furniture Supply Chains
}

\author{
Hui Wang, Jinzhuo Wu,* and Zhili Chen \\ Using an imported timber-based solid wood box bed $(2000 \mathrm{~mm} \times 1800$ \\ $\mathrm{mm}$ ) as the functional unit, the ILCD 2011 midpoint assessment method \\ was used to measure the life cycle carbon emissions of the product. Using \\ this assessment, the Dijkstra algorithm was adopted to determine the \\ shortest supply chain path and to obtain the minimum carbon footprint of \\ the supply chain. Results showed that the total carbon footprint of the \\ wood bed was $464 \mathrm{~kg}$ for the control case. For experimental cases, the \\ carbon footprint ranged from $456 \mathrm{~kg}$ to $517 \mathrm{~kg} \mathrm{CO}$-eq. The upstream \\ process was identified as the primary contributor to the carbon footprint, \\ accounting for $74.6 \%$ to $80.7 \%$ of the total carbon footprint, followed by \\ the downstream and the core-stream processes. Configuration of a timber \\ harvesting system with lower fuel consumption, purchasing timber from \\ areas within shorter transportation distance, and reducing the proportion \\ of incineration for waste treatment were feasible solutions to reduce the \\ carbon footprint of the product. A case study optimizing the low-carbon \\ path for the wooden furniture supply chain determined the shortest path \\ for the participants in each link, such that the minimum total carbon \\ footprint of the supply chain was $463 \mathrm{~kg} \mathrm{CO}_{2}$-eq.
}

Keywords: Solid wood bed; Dijkstra algorithms; Greenhouse gas; Sawn timber; Laminated timber

Contact information: College of Engineering and Technology, Northeast Forestry University, Harbin 150040 China; *Corresponding author:wjz@nefu.edu.cn

\section{INTRODUCTION}

Global climate change caused by carbon emissions has caused considerable adverse impacts to human society and economic development, and as such, has gained more and more attention in world politics, economics, and sciences fields (Li 2011; Mantyka-Pringle et al. 2015). Low carbon manufacturing and carbon reduction have become the core concepts of the sustainable development of human society (Ali et al. 2020; Gierling and Blanke 2021). The carbon footprint of a product is defined as the total carbon dioxide and other greenhouse gases emitted during the product life, from raw material extraction to recycling or disposal (Dong et al. 2014). In order to mitigate climate change and reduce carbon emissions, the product carbon footprint has been widely used in various products to help enterprises understand the carbon emissions associated with their products as well as adopt feasible measures to reduce carbon emissions (Garofalo et al. 2017; Tellnes et al. 2019; Ledgard et al. 2020).

China is the second largest timber consumer and the largest timber importer in the world (Yu et al. 2018). In 2017, the import volume of timber in China was approximately 108.5 million cubic meters, registering a year-over-year growth of $16.1 \%$. In the same year, the wooden furniture exported from China was 19.986 billion dollars (United Nations 
2021). The supply chain of wooden furniture is characterized by a global network with numerous links and complex manufacturing processes. With the increasing demand for wooden furniture, the carbon footprint associated with the supply chain of wooden furniture is also increasing. By analyzing the carbon footprint of wooden furniture, the enterprises in the supply chain, especially the core enterprise, can gain a better understanding of the impacts of the product on climate change and then take appropriate countermeasures, e.g., technology improvement and optimization of supply chain structure, to reduce carbon emissions.

Life-Cycle Assessment (LCA) has been regarded as the most scientifically reliable method currently available for studying and evaluating the environmental impacts of a certain product or process (Ness et al. 2007; Abdallah et al. 2012; Mota et al. 2015). The specific approaches to perform LCA for GHG estimation include process analysis (PALCA)/bottom-up, input-output (IO-LCA)/top-down, and hybrid LCA (the combination of PA-LCA and IO-LCA) (Pandey et al. 2011). Currently, several studies have been conducted to account for the carbon footprint of wooden furniture via the PA-LCA method. For example, González-García et al. (2011) carried out a life cycle assessment on several indoor and outdoor wood products from a cradle-to-gate perspective, using global warming potential as the selected impact category. The results showed that metals, boards, and energy usage were the most contributing elements to the environmental impact of the different products under assessment, with total contributions ranging from $40 \%$ to $90 \%$. González-García et al. (2012) used the life cycle assessment method to determine the environmental profile of a set of wooden furniture in order to facilitate the eco-design of the product. They found that the processes of wooden board production and electricity were the key environmental factors, with contributions of $45 \%$ to $68 \%$ and $14 \%$ to $33 \%$, respectively. By applying eco-design strategies, the environmental profile of the product could be reduced by $14 \%$. Linkosalmi et al. (2016) assessed the greenhouse gas emissions of different wooden furniture in Finland and eight furniture manufacturing processes were evaluated to identify the major factors that contributed to greenhouse gas emissions. The results showed that raw materials had the most substantial impact on greenhouse gas emissions, followed by processing and assembling. The process of packaging and transportation had the least impact. Lin and Huang (2016) compared the carbon footprint of two wooden bedside cupboards of the same size made with different raw materials and found that the carbon footprint of solid wood products $\left(16.5 \mathrm{~kg} \mathrm{CO}_{2}-\mathrm{eq}\right)$ was larger than that of veneer particle board products $(12.26 \mathrm{~kg} \mathrm{CO}$-eq). The upstream raw material was the largest carbon emissions source in wood-based products, accounting for $61 \%$ and $95 \%$ of the total emissions of the two products, respectively. Medeiros et al. (2017) diagnosed the life cycle environmental performance of an office cabinet based on ISO standard 14044 (2006) and the International Reference Life Cycle Data System (ILCD) 2011 midpoint and evaluated the transport scenarios and post-use options. The results showed that the most considerable environmental impact of the furniture life cycle was due to the distances covered and production of the primary raw material, i.e., wood medium-density particleboard (MDP). Environmental tradeoffs for truck fuel switches and environmental gains were achieved for the distribution of MDP from closer suppliers via truck, as well as from current supplier via truck and ship in the major categories. It is noted that previous studies indicated that the raw material had greater contribution to the carbon footprint of wooden furniture products, which involves many activities, e.g., raw material extraction and rough machining, transportation, and auxiliary material production. However, the impacts of the upstream processes on the life cycle carbon footprint accounting for different

Wang et al. (2021). "Wooden furniture carbon footprint," BioResources 16(4), 6870-6890. 6871 
wooden furniture products were rarely reported, which may hinder the carbon reduction of the wooden furniture supply chain.

Similar to other products, a wooden furniture supply chain also consists of different entities, including suppliers, manufacturers, distributors, users, and recyclers. Under the background of green and low-carbon development, these industry practitioners are under increasing pressure to continuously reduce the negative environmental impact of wooden furniture product supply chains. By selecting appropriate participants in different links and at different levels, a low-carbon path for a wooden furniture supply chain can be realized in order to improve the environmental friendliness of the product and enhance the competitiveness of the enterprises involved (Yin and Liu 2014). Currently, most studies on carbon footprint accounting for wooden furniture focused on the production process and proposed production process carbon reduction countermeasures, e.g., using auxiliary materials with low-carbon emissions, reducing the use of paint, and improving the painting technology (Bai et al. 2013; Lin and Huang 2016; Kwangsawat and Rugwongwan 2017). However, the carbon emissions of the wooden furniture supply chain was contributed by the upstream and downstream enterprises together; the carbon reduction behavior of a single enterprise cannot effectively cut down the life cycle carbon emission of the product supply chain.

In order to realize low-carbon management of a product supply chain, Guo (2017) proposed the definition of a product carbon chain and established a carbon footprint calculation model based on the LCA method. The carbon chain optimization problem was simplified as a shortest path problem, and Dijkstra's algorithm was used to obtain the optimal path of the product carbon chain with the lowest carbon emissions. Liu and Wang (2016) adopted the life cycle assessment method to calculate the carbon footprint of wooden cabinets, which includes both domestic gate-to-gate stages and imported raw material cradle-to-gate stages that may be located in different countries (mid-Europe, Northern Europe, and the United States). They found that large variances existed in the carbon emissions of imported materials under different import patterns and that the contribution structure of the total carbon footprint was different under these import patterns.

It was suggested that the Northern Europe patterns should be shifted to other import patterns, which could drastically reduce the carbon footprint of wood cabinets. Since the wooden cabinet was produced from imported materials and was intended for export to other countries, the scenario of domestic distribution and discharge should also be considered. In summary, the network structure of an imported timber-based wooden furniture supply chain was more complex compared to that of domestic timber-based supply chains, and the corresponding carbon footprint optimization of the product supply chains were not well documented. Therefore, it is necessary to study the low-carbon path optimization for wooden furniture supply chains.

The objectives of the study are to: (1) establish a cradle-to-grave carbon footprint model for a specific type of wooden furniture via the LCA method; (2) evaluate the carbon emissions of the wooden furniture supply chain and conduct sensitivity analysis by considering different import sources, disposal modes, etc.; and (3) carry out low-carbon path optimization for the wooden furniture supply chain.

Wang et al. (2021). "Wooden furniture carbon footprint," BioResources 16(4), 6870-6890. 6872 


\section{EXPERIMENTAL}

\section{Product Carbon Footprint Calculation Method}

PAS standard 2050 (2011), ISO standard 14067 (2018), and the GHG protocol (2011) are widely used standards for product-level carbon footprint accounting (Bai et al. 2014). They are based on ISO $14040 \& 14044$ (2006). Under these standards, LCA method is usually used for better understanding the environmental impacts of products in terms of their whole life-cycle. It can be used for carbon footprint accounting of wooden furniture as well as helping to improve the environmental performance during product eco-design and supply chain management (Hawkins et al. 2015). LCA can be performed in four steps, including goal and scope definition, life cycle inventory analysis, life cycle impact assessment, and interpretation of the results (AzariJafari et al. 2016). In this study, PAS 2050 (2011) was used to account for the carbon footprint of a solid wood bed produced by a wooden furniture manufacturer in Northeast China. The PAS standard 2050 (2011) provides organizations a consistent method for measuring the greenhouse emissions starting from the collection of the raw materials though its production and disposal (Garcia and Freire 2014). It can help organizations to identify hotspots and reduce carbon emissions in their product supply chain. The calculation formula for the carbon footprint is expressed by Eq. 1,

$$
G H G=\sum_{i=1}^{n} A_{i} \times E_{i}
$$

where $G H G$ represents the carbon footprint of the product, $A_{\mathrm{i}}$ refers to the quantity or intensity data of a substance or activity (mass $/$ volume $/ \mathrm{km} / \mathrm{kWh}$ ), and $E_{\mathrm{i}}$ represents the unit greenhouse gas emission factor $\left(\mathrm{CO}_{2}\right.$-eq per unit).

\section{Research material}

Wooden furniture primarily includes solid wooden furniture and panel furniture. In recent years, the demand for solid wooden furniture dramatically increased due to an increase of awareness of environmental protection and life quality; therefore, it is of great importance to study the carbon footprint of solid wooden furniture. Compared to other solid wooden furniture, solid wood beds are more common in the market. In this study, a large scale wooden furniture manufacturer located in Yichun city, Northeast China, was investigated, which primarily produced solid wooden furniture and panel furniture and focused on mid and high end customers. It can produce a series of solid wood beds of different types (platform bed, box bed, and pneumatic bed) and various dimensions (king size, queen size, full size, and twin size). Since the solid wood box bed $(2000 \mathrm{~mm} \times 1800$ $\mathrm{mm}$ ) requires more work and consumes lots of wood, it was used as the research object. The product was composed of a headboard, partitions, pull plates, and bed drawers. The primary material used was beech sawn timber and radial pine laminated timber.

\section{Goal and scope}

The goal of this study was to evaluate the carbon emissions of a solid wood box bed supply chain based on imported timber and domestic manufacturing and use, as well as identify the hotpots throughout the supply chain, in order to provide data for low-carbon path optimization in the following analysis. Therefore, the functional unit was a solid wood box bed with dimensions $2000 \mathrm{~mm} \times 1800 \mathrm{~mm}(80 \mathrm{~kg})$. The system boundary of the solid wood bed supply chain was defined as the entire life cycle, i.e., from cradle to grave, which included timber acquisition and auxiliary material production, procurement and 
transportation, material preliminary processing, on-site manufacturing, warehousing, sales distribution, use, and disposal. These processes can generally be divided into three macroareas or processes: upstream processes, core-stream processes, and downstream processes. The upstream processes involved three stages, including timber acquisition and production of other auxiliary materials, procurement and transportation, and preliminary material processing, i.e., sawn timber processing and laminated timber processing (as shown in Fig. 1a). In this stage, greenhouse gas emissions came from the raw material acquisition and production, the consumption of fuels during transportation, and the usage of electricity during the initial processing of the materials. Depending on the sources of the timber used, the transportation distance and transport mode may vary greatly. The core-stream processes included material preparation, finishing, spray coating, and packaging, as shown in Fig. 1b. Since the direct emissions during furniture production was limited, accounting for less than $1 \%$ of the total emissions, the direction emission data was not considered in this study, according to the common verification criteria for product carbon footprints (Lin and Huang 2016). Greenhouse gas emissions were primarily related to the use of electricity for production and on-site storage. In the downstream processes, the greenhouse gas emissions from sales and distribution, i.e., transportation and storage, and disposal treatment, i.e., recycling and incineration/landfill, were considered (as shown in Fig. 1c). The consumption of fuel and energy during transportation and waste treatment were the primary source of greenhouse gas emissions. In order to simplify the supply chain of a solid wood bed, it was assumed the greenhouse gas emissions during the stage of use were zero and all the used wood beds were incinerated or placed in a landfill without considering the recycling of the furniture.

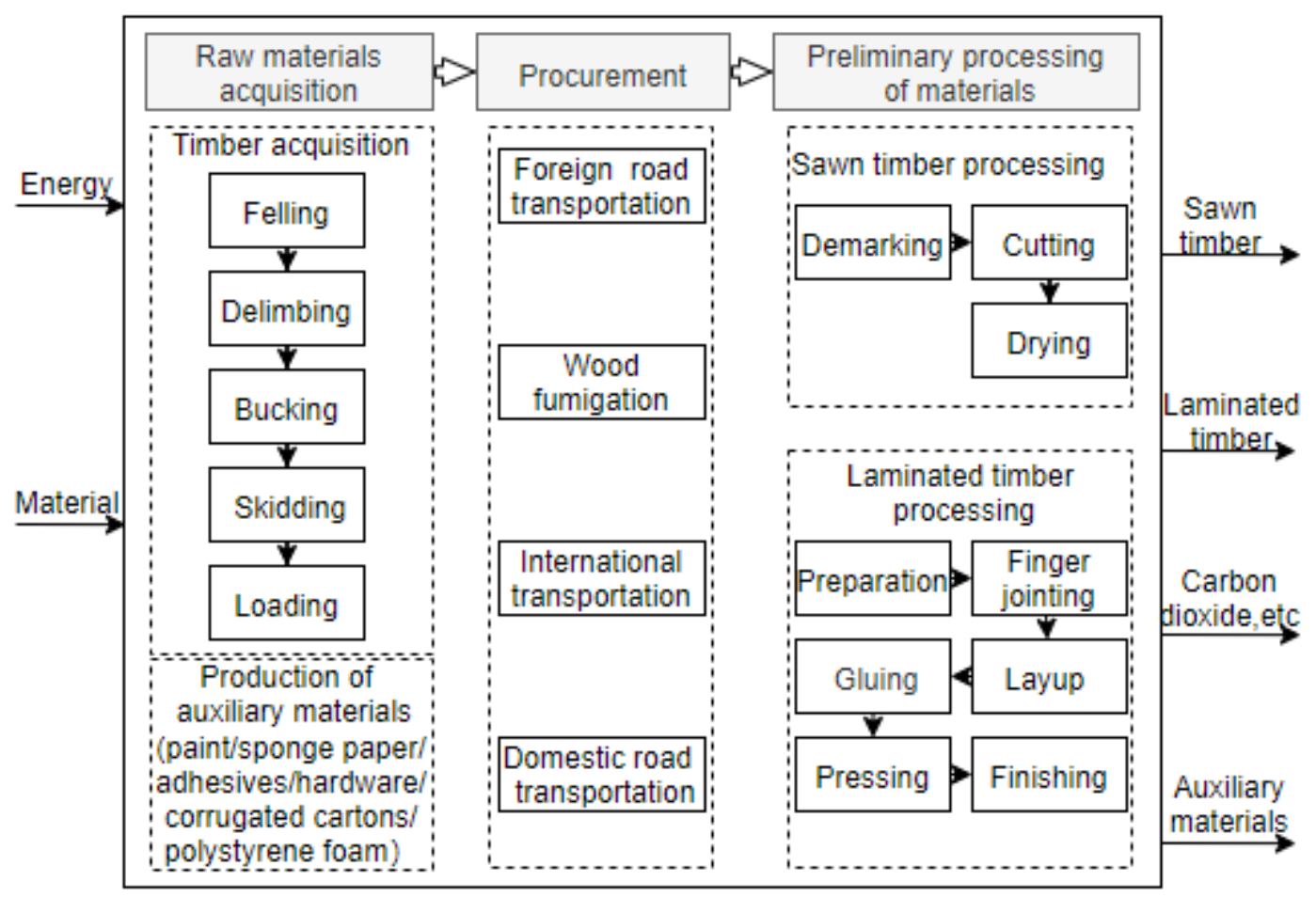

(a) Upstream process 


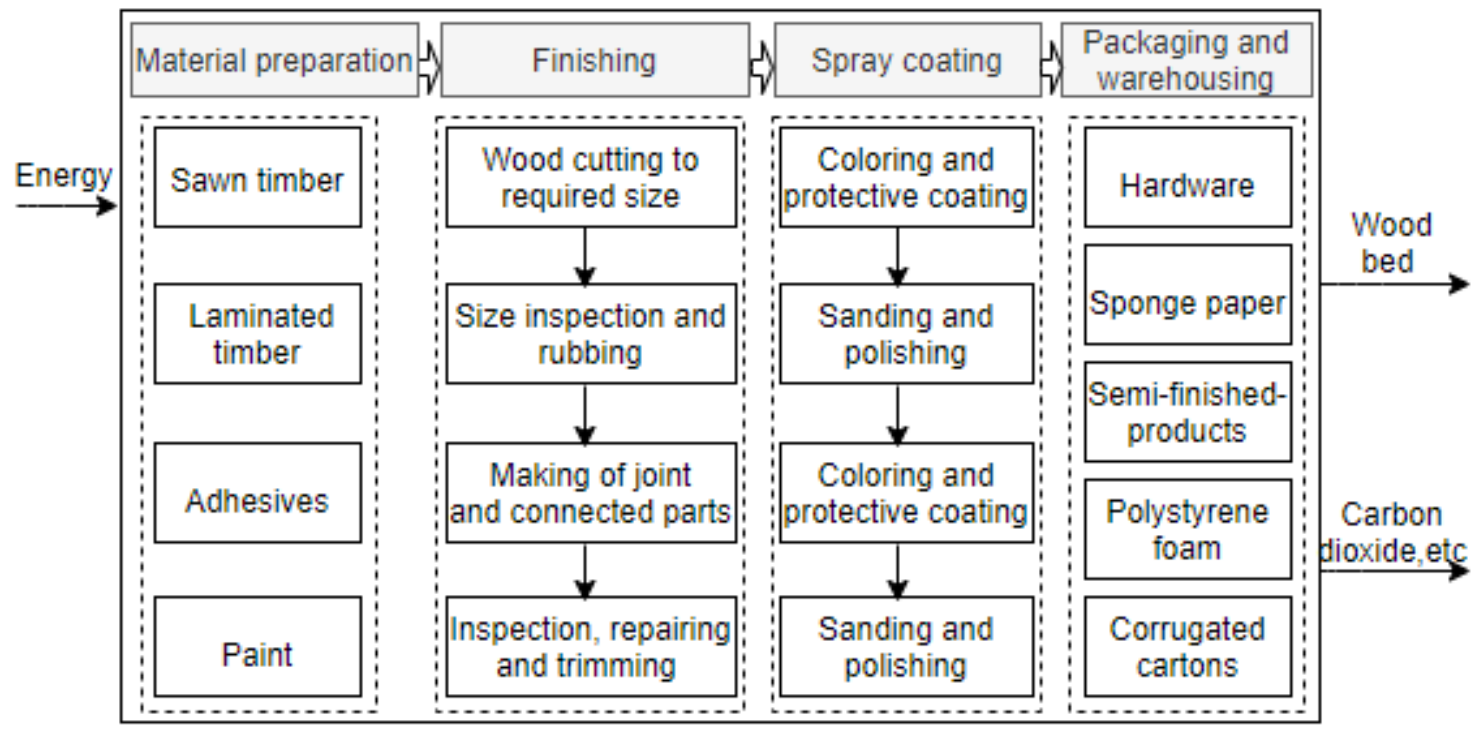

(b) Core-stream process

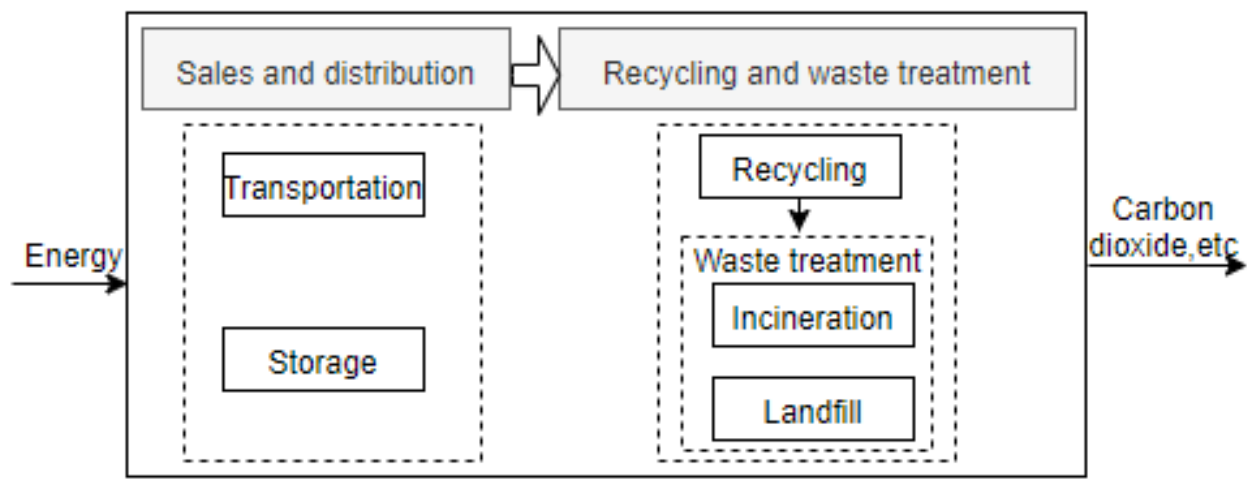

(c) Downstream process

Fig. 1. System boundaries of a solid wood bed

Life cycle inventory analysis

A life cycle inventory analysis focuses on the identification and quantification of all resources used, e.g., energy, water, raw materials, and processed materials, to produce a product and all substances released into the environment, e.g., pollutants into the air, soil, and water (Nieuwlaar 2004). In this study, the resource usage and greenhouse gas emissions $\left(\mathrm{CO}_{2}\right.$ equivalent) in different stages of the solid wood bed supply chain were quantified.

A solid wood bed as a functional unit needed to consume $0.11 \mathrm{~m}^{3}$ of sawn timber and $0.36 \mathrm{~m}^{3}$ of laminated timber. It was assumed that the average recovery rate for sawn timber and laminated timber were 55\% and 85\%, respectively (Lin et al. 2011). The loss of other raw materials was negligible. Therefore, the total volume of timber consumed was $0.97 \mathrm{~m}^{3}$.

During the up-stream processes, the acquisition of timber is a key source of greenhouse gas emissions (Lin and Huang 2016, Linkosalmi et al. 2016). The emission factors of timber harvesting were determined by the configuration of the log harvesting system, machine rate, and fuel consumption rate. According to the UN Comtrade Database, the primary forest products, i.e., logs and sawn timber, imported by China were primarily sourced from North America, Russia, New Zealand, Papua New Guinea, and Canada in the 
recent years (United Nations 2021). The fuel consumption rates of the timber harvesting systems commonly used in these areas ( $\mathrm{S} 1$ to $\mathrm{S} 5$ ) by process and carbon emissions are shown in Table 1. It is noted that in order to compare the carbon emissions of different systems, the same type of loader was used in all the systems.

Table 1. Fuel Consumption Rates of Common Ground-based Timber Harvesting Systems by Process $\left(\mathrm{L} \cdot \mathrm{m}^{-3}\right)$ and Carbon Emissions $\left(\mathrm{CO}_{2}-\mathrm{eq} \cdot \mathrm{m}^{-3}\right)$

\begin{tabular}{|c|c|c|c|c|c|}
\hline \multirow{2}{*}{ Process } & \multicolumn{2}{|c|}{ Cut to Length (CTL) } & \multicolumn{3}{|c|}{ Whole-tree (WT) } \\
\hline & S1 & S2 & S3 & S4 & S5 \\
\hline Felling & $\begin{array}{c}\text { Feller buncher } \\
0.34^{\mathrm{a}}\end{array}$ & $\begin{array}{c}\text { Harvester } \\
1.14^{\mathrm{b}}\end{array}$ & $\begin{array}{c}\text { Feller buncher } \\
0.34^{\mathrm{a}}\end{array}$ & $\begin{array}{c}\text { Chainsaw } \\
0.123^{\mathrm{e}}\end{array}$ & \multirow{3}{*}{$\begin{array}{c}\text { Chainsaw } \\
0.428^{f}\end{array}$} \\
\hline Delimbing & - & $\begin{array}{c}\text { Harvester } \\
-\end{array}$ & - & $\begin{array}{c}\text { Chainsaw } \\
0.087^{e} \\
\end{array}$ & \\
\hline Processing & $\begin{array}{c}\text { Processor } \\
0.52^{\mathrm{a}}\end{array}$ & $\begin{array}{c}\text { Harvester } \\
-\end{array}$ & $\begin{array}{c}\text { Processor } \\
0.52^{\mathrm{a}}\end{array}$ & $\begin{array}{c}\text { Processor } \\
0.52^{\mathrm{a}}\end{array}$ & \\
\hline Skidding & $\begin{array}{c}\text { Forwarder } \\
0.31^{\mathrm{a}}\end{array}$ & $\begin{array}{c}\text { Forwarder } \\
0.57^{\circ}\end{array}$ & $\begin{array}{l}\text { Grapple } \\
\text { skidder } \\
0.419^{d}\end{array}$ & $\begin{array}{l}\text { Grapple } \\
\text { skidder } \\
0.419^{d}\end{array}$ & $\begin{array}{l}\text { Grapple } \\
\text { skidder } \\
0.419^{d}\end{array}$ \\
\hline Loading & $\begin{array}{l}\text { Loader } \\
0.36^{\mathrm{a}}\end{array}$ & Forwarder & $\begin{array}{l}\text { Loader } \\
0.36^{a}\end{array}$ & $\begin{array}{l}\text { Loader } \\
0.36^{a}\end{array}$ & $\begin{array}{l}\text { Loader } \\
0.36^{\mathrm{a}}\end{array}$ \\
\hline $\begin{array}{l}\text { Carbon } \\
\text { emissions }\end{array}$ & 4.25 & 4.75 & 4.55 & 4.10 & 3.17 \\
\hline
\end{tabular}

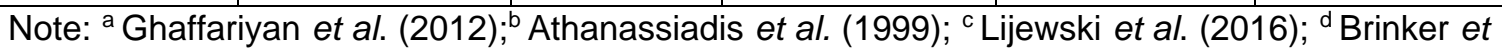
al. (2002) and Akhtari et al. (2019); ' Wang et al. (2004); and ${ }^{\dagger}$ Popovici (2013). The fuel used for chain saw was gasoline, while the fuel used in the other equipment was diesel. The emission factors of gasoline and diesel fuel were $2.361 \mathrm{~kg} \mathrm{CO}_{2}$-eq per liter and $2.778 \mathrm{~kg} \mathrm{CO}_{2}$-eq per liter, respectively. Skidding distance was assumed to be $350 \mathrm{~m}$ for skidders.

Table 2. Carbon Emission Inventory Data of Auxiliary Materials for A Solid Wood Bed Functional Unit

\begin{tabular}{|c|c|c|c|}
\hline Auxiliary Materials & Consumption $(\mathrm{kg})$ & $\begin{array}{c}\text { Carbon Emission Factor } \\
\left(\mathrm{kg} \mathrm{CO}_{2}-\mathrm{eq} \cdot \mathrm{kg}^{-1}\right)\end{array}$ & $\begin{array}{c}\text { Carbon Emissions } \\
\left(\mathrm{kg} \mathrm{CO}_{2} \text {-eq }\right)\end{array}$ \\
\hline Paint & 30.84 & 2.86 & 88.20 \\
\hline Hardware & $5.26^{\mathrm{a}}$ & $0.59^{\mathrm{b}}$ & 3.10 \\
\hline Adhesives & 2.54 & 2.63 & 6.68 \\
\hline Sponge paper & 0.20 & 2.10 & 0.42 \\
\hline Corrugated cartons & 15.61 & 0.66 & 10.30 \\
\hline Polystyrene foam & 1.26 & 3.38 & 4.26 \\
\hline Note: ${ }^{\mathrm{a}}$ The unit is USD; and ${ }^{\mathrm{b}}$ The unit is $\mathrm{kg} \mathrm{CO}_{2}$-eq.USD ${ }^{-1}$ \\
\hline
\end{tabular}

For the control case, the beech timber was assumed to be imported from Germany and the Pinus radiata wood was imported from New Zealand. The corresponding ocean transportation distances were approximately $20700 \mathrm{~km}$ and $10080 \mathrm{~km}$, respectively. A carbon emission rate of $0.0177 \mathrm{~kg} \mathrm{CO} 2 \cdot \mathrm{t}^{-1} \cdot \mathrm{km}^{-1}$ for ocean shipping was considered $(\mathrm{He}$ 2016). The timber harvesting system $S 1$ was used to determine the carbon emissions of log 
acquisition. The exported timber was transported from the harvesting site to the export port at a distance of $500 \mathrm{~km}$ and the carbon emission rate was $0.0143 \mathrm{~kg} \mathrm{CO} \cdot \mathrm{m}^{-3} \cdot \mathrm{km}^{-1}$ (Healey et al. 2009). Wood fumigation is required in wood import and export in order to get rid of pests. For the control case, the exported timber was assumed to be treated with methyl bromide for $48 \mathrm{~h}$ at temperatures greater than $21{ }^{\circ} \mathrm{C}$ and the usage of methyl bromide was $48 \mathrm{~g} \cdot \mathrm{m}^{-3}$. The emission factor of methyl bromide was assumed to be $0.36 \mathrm{~kg} \mathrm{CO}$-eq $\mathrm{kg}^{-1}$ (Anil et al. 2020). The domestic road transportation distance from the importing port to the manufacturing plant was approximately $1000 \mathrm{~km}$ and the corresponding carbon emission rate was $0.1553 \mathrm{~kg} \mathrm{CO} \cdot \mathrm{t}^{-1} \cdot \mathrm{km}^{-1}$ (Xie and Wang 2011). The imported timber was initially processed into sawn timber and laminated timber near the importing port before entering into the furniture manufacturing process. The sawing process involved demarking and the cutting of the $\log$ s into sections, which were sawn into timber boards. A conventional drying method was used to control the time and temperature of the drying kiln. According to a state-of-the-art of sawing process in China, the average carbon emissions of the sawing and drying process were approximately $40 \mathrm{~kg} \mathrm{CO}$-eq per cubic meter (Shen et al. 2016; Chen et al. 2019). Laminated timber is made of board lamellas, which are finger-jointed lengthwise and then glued together with parallel fibers. The technical process of laminated timber includes lumber preparation, finger jointing, layup and gluing, pressing, and finishing. The average carbon emissions of the laminated timber production process were approximately $100 \mathrm{~kg} \mathrm{CO}$-eq per cubic meter (Dai et al. 2018; Chen et al. 2019). Since the amount of auxiliary materials, e.g., paint, hardware, adhesives, sponge paper, corrugated cartons, and polystyrene foam, were minute, the emission factors of these materials were referred from the databases (ELCD, Ecoinvent, USA Input Output Industry Data, and USLCI) in the SimaPro 9.0 software. The usage of auxiliary materials for a solid wood bed functional unit and the corresponding emission factors are shown in Table 2.

In the core-stream processes, the carbon emissions were primarily from the consumption of electricity caused by the usage of equipment in the material preparation, finishing, spraying and coloring, and assembling and packaging stages. Additional electricity usage from the storage of the parts of the products was also considered. The emission factor of electricity $\left(1.0935 \mathrm{~kg} \mathrm{CO} 2-\mathrm{eq} \cdot \mathrm{kWh}^{-1}\right)$ was sourced from the baseline emission factor for the regional power grid in Northeast China (National Development and Reform Commission of China 2021). The electricity consumption by the manufacturing equipment was calculated by Eq. 2,

$$
E C=P E \times P C \times P V
$$

where $E C$ represents the power consumption of the manufacturing equipment $(\mathrm{kWh}), P E$ refers to the power of the manufacturing equipment $(\mathrm{kW}), P C$ refers to the processing time $\left(\mathrm{h} \cdot \mathrm{m}^{-3}\right)$, and $P V$ refers to the processing quantity $\left(\mathrm{m}^{3}\right)$. The related parameters, e.g., the power of the equipment and the production capacity, were from the equipment data plate, on-site measurements, and the experience values estimated by the operators. The use of electricity for the automatic painting production line was $0.53 \mathrm{kWh} \cdot \mathrm{m}^{-2}$. The electricity consumption by warehousing was estimated according to the warehouse area $\left(\mathrm{m}^{2}\right)$, power consumed per unit area $\left(\mathrm{kWh} \cdot \mathrm{m}^{-2}\right)$, and the quantity of solid wooden furniture stored (sets). Based on the above parameters, a solid wood bed functional unit required $31.2 \mathrm{kWh}$ of electricity for manufacturing and painting and $1.8 \mathrm{kWh}$ of electricity for warehousing. It is noted that the scrap materials will be recovered in the core part of operation and used as fuel and the sawdust will be sold to a third party. However, the carbon emissions associated with this operation were not considered in this study due to the limit of data collection.

Wang et al. (2021). "Wooden furniture carbon footprint," BioResources 16(4), 6870-6890. 6877 
In the downstream processes, only the carbon emissions during product distribution, recycling and waste treatments were considered in this study. In fact, wooden furniture can be used for tens of years, so it can be regarded as a carbon sink to some extent. During the usage stage of wooden furniture, the carbon emissions were very limited, which can be neglected. The commonly used methods for wooden furniture waste treatment included incineration and landfill dumping. Both methods will generate a certain amount of greenhouse gas. For the control case, it was assumed that the full capacity of a 6-ton box truck with a fuel consumption rate of 11 liters per $100 \mathrm{~km}$ were used in product distribution and the average transportation distances for the line-haul transport and local distributions were $1000 \mathrm{~km}$ and $40 \mathrm{~km}$, respectively. The used wooden furniture was locally disposed, which was recycled by professional recycling agencies via dump trucks. Since the waste processing facility or landfilling site is usually located in the urban fringe, a longer transportation distance of $50 \mathrm{~km}$ was assumed. The allocation of wooden furniture waste treatment in the control case was $60 \%$ for incineration and $40 \%$ for landfill dumping.

\section{Low-carbon Path Selection Method}

In the timber-related businesses, supply chain management is essential not only for controlling the supply chain cost but also for limiting the carbon footprint of the product (Garcia and Freire 2011). The wooden furniture supply chain is composed of multiple entities, including raw materials, e.g., wood, hardware, adhesives, etc., producers, suppliers, furniture manufacturers, retailers, users, and recycling agencies. The network structure of a wooden furniture supply chain is shown in Fig. 2.

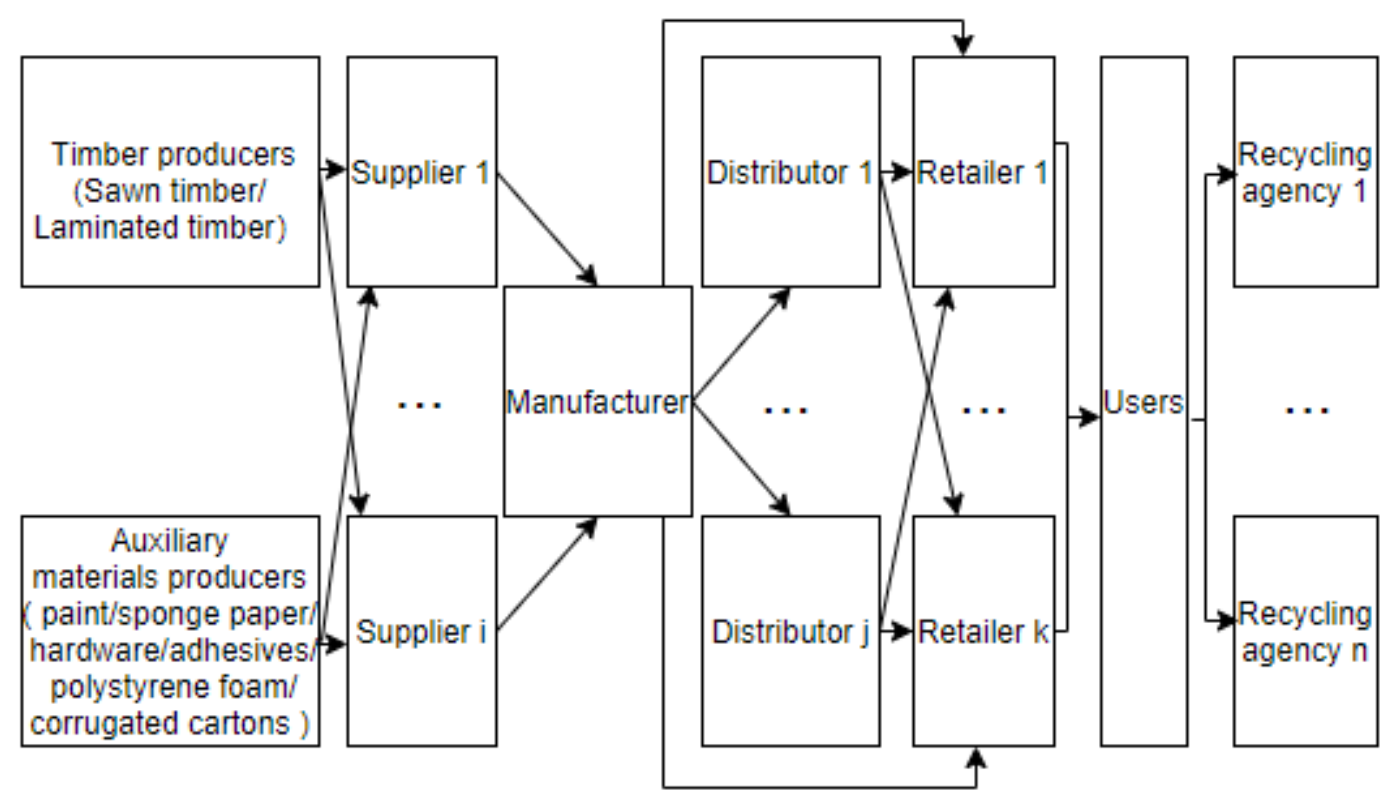

Fig. 2. Network structure of the wooden furniture supply chain

The manufacturer, as the core of the supply chain, purchases raw materials from selected suppliers, and delivers the products to retailers through direct sales or distribution. The final products are recycled via recycling agencies or treated via landfill dumping or incineration. The raw material producers, suppliers, manufacturers, retailers, and recycling agencies are the key links in the supply chain of wooden furniture, and their carbon emissions can greatly determine whether the supply chain of wooden furniture meets low- 
carbon development requirements. Since each type of company has a certain number of entities of the same nature and the products may undergo different activities in these entities with different levels of carbon emissions, the carbon footprint of wooden furniture may drastically vary from the perspective of the supply chain. Therefore, it is critically important to design a low-carbon path by selecting appropriate companies in each link of the supply chain in order to lower the carbon footprint of the wooden furniture products.

The Dijkstra algorithm was used to identify the optimal low-carbon path of the wooden furniture supply chain. It is an effective algorithm to solve the single-source shortest path problem for a directed graph with nonnegative edge weights (Sunita and Garg 2021). Assuming that $V$ is a point in a directed graph $G$, and $E$ is the edge connecting the points in $G$, then graph $G$ can be expressed by Eq. 3,

$$
G=G(V, E)
$$

The minimum value of the path $\left(u_{0}\right)$ can be calculated according to Eq. (4),

$$
W\left(u_{0}\right)=\min \sum_{u\left(p_{i}, p_{j}\right)} W(e)
$$

where $W(e)$ is the weight of the line $u\left(p_{i}, p_{j}\right)$ that connects the two points $p_{i}, p_{j}(W(e) \geq 0)$, and $W(u)$ is the length of the path $u$ (Wang et al. 2019).

The Dijkstra algorithm basically starts at a node (the source node) and it analyzes the graph to find the shortest path between that node and all the other nodes in the graph. The algorithm keeps track of the currently known shortest distance from each node to the source node and it updates these values if it finds a shorter path. Once the algorithm has found the shortest path between the source node and another node, that node is marked as "visited" and added to the path. The process continues until all the nodes in the graph have been added to the path. Then, a path can be obtained that connects the source node to all other nodes following the shortest path possible to reach each node (Javaid 2013; Wang and $\mathrm{Li}$ 2014).

Since a furniture manufacturer usually purchases raw materials from different suppliers, the network structure of the wooden furniture supply chain was simplified and the suppliers, furniture manufacturers, distributors, retailers, and recycling agencies were used as nodes. The carbon emissions of different producers were allocated to the nodes of different suppliers. In the directed graph $G$, the weight of the edge was expressed by carbon emissions. Besides the starting point and the end point, the dichotomy method was used to assign the edge weights, as shown in Eq. 5,

$$
W=\left\{\begin{array}{c}
e_{i}+\frac{e_{i+1}}{2} \\
\frac{e_{j}+e_{j+1}}{2} \\
\frac{e_{k-1}}{2}+e_{k}
\end{array}\right.
$$

where $W$ is the weight value of the edge, $e$ represents the carbon footprint value of the node, $i$ is the front-end point, $j$ is the intermediate node point, and $k$ is the end point.

Using this method, a weighted directed graph of the wooden furniture supply chain was established. The Dijkstra algorithm was adopted to determine the shortest path of the graph and the minimum total carbon footprint of the wooden furniture supply chain was determined. 


\section{RESULTS AND DISCUSSION}

\section{Carbon Footprint of the Control Case}

The carbon footprint accounting model was established using the life cycle analysis software SimaPro 9.0, while the ILCD 2011 midpoint method was used to calculate the carbon emissions ( $\mathrm{kg} \mathrm{CO}_{2}$-eq) of a solid wood bed functional unit. The carbon emissions of different processes with detailed contributors are shown in Table 3. Results showed that the total carbon footprint of the solid wood bed was $464 \mathrm{~kg} \mathrm{CO}$-eq. The highest carbon emissions were from the upstream processes (364 $\mathrm{kg} \mathrm{CO}_{2}$-eq or $\left.78.49 \%\right)$, followed by the downstream processes $\left(63.7 \mathrm{~kg} \mathrm{CO}_{2}\right.$-eq or $\left.13.7 \%\right)$, and the core-stream processes $(36.1 \mathrm{~kg}$ $\mathrm{CO}_{2}$-eq. or $7.78 \%$ ).

Table 3. Carbon Emissions of Different Processes and Detailed Contributors

\begin{tabular}{|c|c|c|c|}
\hline Processes & Contributors & $\begin{array}{l}\text { Carbon Emissions } \\
\quad\left(\mathrm{kg} \mathrm{CO} \mathrm{CO}_{2}-\mathrm{eq}\right)\end{array}$ & Percentage (\%) \\
\hline \multirow{8}{*}{ Upstream process } & $\begin{array}{c}\text { Auxiliary materials } \\
\text { production }\end{array}$ & 112.97 & 24.34 \\
\hline & Log acquisition & 4.13 & 0.89 \\
\hline & Foreign road transportation & 6.95 & 1.50 \\
\hline & Wood fumigation & 0.02 & $0.00^{\mathrm{a}}$ \\
\hline & Ocean transportation & 114.53 & 24.68 \\
\hline & $\begin{array}{l}\text { Domestic road } \\
\text { transportation }\end{array}$ & 40.76 & 8.78 \\
\hline & Sawn timber processing & 8.23 & 1.77 \\
\hline & $\begin{array}{l}\text { Laminated timber } \\
\text { processing }\end{array}$ & 76.63 & 16.51 \\
\hline \multirow[t]{2}{*}{ Core-Stream process } & $\begin{array}{l}\text { Consumption of electricity } \\
\text { in manufacturing and } \\
\text { painting }\end{array}$ & 34.12 & 7.35 \\
\hline & $\begin{array}{c}\text { Electricity usage from the } \\
\text { storage }\end{array}$ & 1.97 & 0.42 \\
\hline \multirow{5}{*}{ Downstream Process } & Line-haul transport & 4.07 & 0.88 \\
\hline & Local distribution & 0.16 & 0.03 \\
\hline & Recycling & 0.2 & 0.04 \\
\hline & Incineration & 41.1 & 8.86 \\
\hline & Landfill dumping & 18.2 & 3.92 \\
\hline Total & - & 464.04 & 100.00 \\
\hline
\end{tabular}

Note: ${ }^{a}$ The numerical value is 0.004 , which is less than 0.01 .

In the upstream process, ocean transportation was the largest contributor, which was followed by auxiliary materials production, initial processing (laminated timber and sawn timber processing), and domestic road transportation. The carbon footprint contributions of $\log$ acquisition, foreign road transportation, and wood fumigation were 
relatively lower (less than $1.5 \%$ ). The contribution of laminated timber processing was greater than that of sawn timber processing in terms of carbon emissions. This is due to the fact that more laminated timber was used $\left(0.36 \mathrm{~m}^{3}\right)$ in a solid wood bed functional unit and the carbon emissions for producing laminated timber was considerably higher than those of sawn timber. In the core-stream processes, the use of electricity in manufacturing and painting was identified as the major source of carbon emissions. In the downstream processes, the major emissions source was waste treatment (Incineration and landfill dumping), followed by product distribution (line-haul transport and local distribution) and recycling.

The results indicated that the largest contribution to the carbon footprint occurred at the upstream processes, which were consistent with the results of previous studies (Bai et al. 2013; Lin and Huang 2016; Liu and Wang 2016; Linkosalmi et al. 2016; Medeiros et al. 2017). For example, Liu and Wang (2016) analyzed the carbon footprint of wooden cabinets, which was composed of both domestic "gate to gate" stages and imported raw material "cradle to gate" stages. They found that the carbon footprint contribution of the imported raw material "cradle to gate" stages was greater than that of the domestic "gate to gate" stages and products with imported raw materials from Northern Europe and the global market yielded the highest carbon footprint. Medeiros et al. (2017) carried out a full life cycle assessment on a sliding door filing cabinet and compared the environmental impact of different transportation strategies and the selection of different fuels for transportation. The results indicated that the most substantial environmental impact of the furniture life cycle was due to the transportation distance covered and production of the primary raw material, i.e., wood medium-density particleboard (MDP). Therefore, choosing low-carbon raw materials, designing reasonable transportation routes, and promoting the use of green fuels are effective ways to promote the low-carbon development of wooden furniture products. The carbon footprint accounting model in the control was established to help enterprises and organizations understand the life-cycle carbon emissions of the studied solid wood bed, and identify the most intensive emission sectors; thus, effective countermeasures for carbon emissions reduction and the optimization of resource distribution and utilization could be proposed (Kulak et al. 2016). However, many uncertainties still remain during the assessment of product carbon footprints, e.g., emissions factors, transportation distances, the configuration of timber harvesting systems, waste treatment modes, etc.

\section{Uncertainty Analysis of Carbon Footprints}

Uncertainty analysis refers to a systematic procedure to quantify the uncertainty introduced in the results of an LCI analysis due to the cumulative effects of model imprecision, input uncertainty, and data variability (ISO 14040 2006). The major types of uncertainty analysis include data collection related uncertainty, model correctness related uncertainty, and model completeness related uncertainty (Anil 2010). In this study, a Monte Carlo analysis was used to capture and quantify an uncertainty range of an inventory result based on given uncertainty information of the control case. The 95\% confidence interval was $(414,550)$ with an average of $464 \mathrm{~kg} \mathrm{CO}_{2}$-eq. The standard deviation was $35.9 \mathrm{~kg}$ $\mathrm{CO}_{2}$-eq and the dispersion coefficient was $7.75 \%$. The probability distribution of the eigenvalues is shown in Fig. 3. It is shown that the degree of dispersion was not exceptionally large, and the accuracy of the evaluation result was high.

Wang et al. (2021). "Wooden furniture carbon footprint," BioResources 16(4), 6870-6890. 6881 


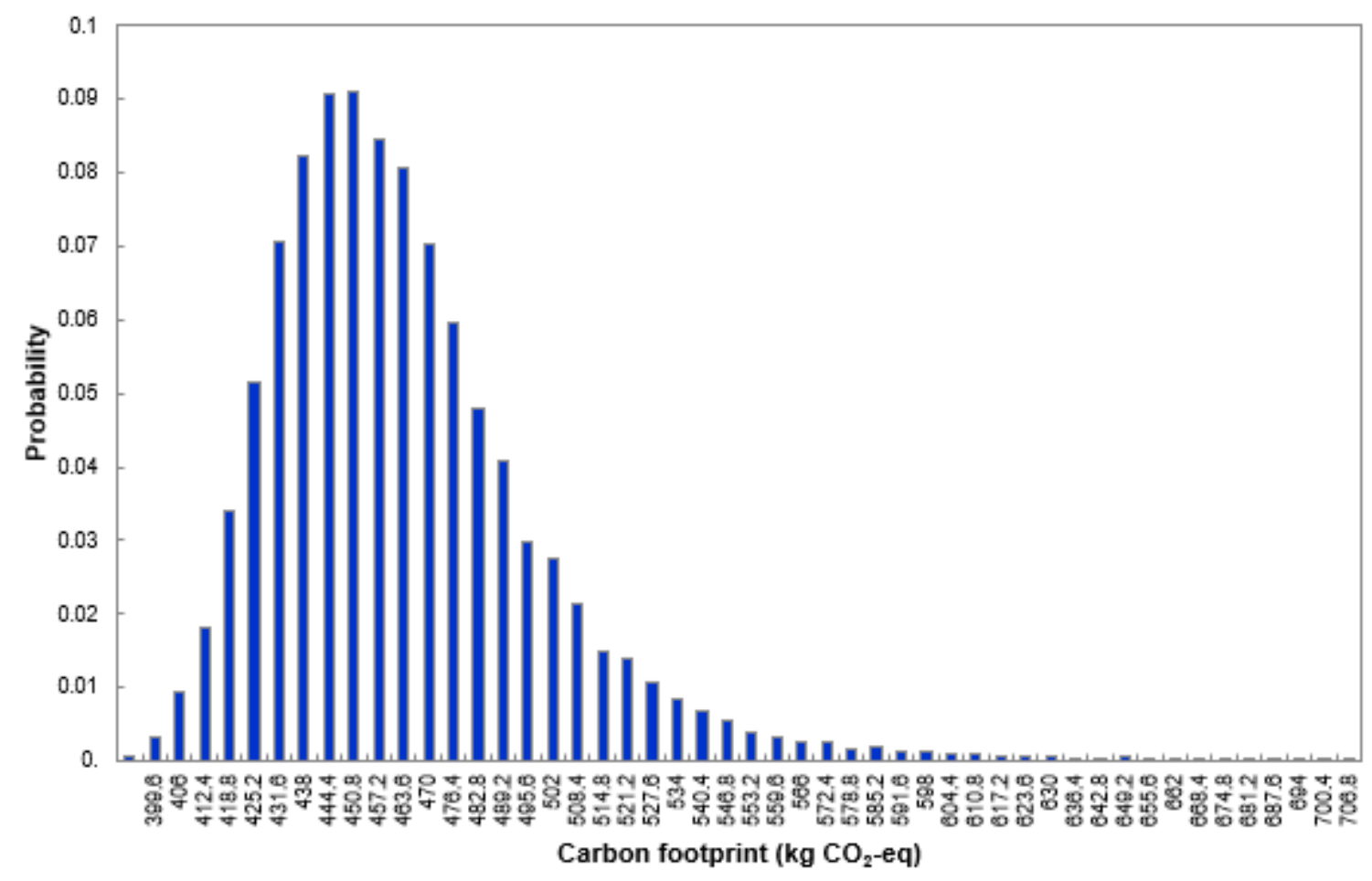

Fig. 3. Probability distribution of the carbon footprint for a solid wood bed functional unit

A sensitivity analysis was also conducted based on different scenarios in order to further compare the life cycle carbon footprint of a solid wood bed. The carbon footprint of a timber harvesting system may drastically vary due to differences in configuration and machine efficiency. Figure 4a shows the carbon footprint of a wooden bed under different timber harvesting systems. The configurations of the timber harvesting systems considered included S1 (control case), S2, S3, S4, and S5, which were described in Table 1. It is shown that the timber harvesting system had less impact on the total carbon footprint of the product, which varied from $463 \mathrm{~kg} \mathrm{CO}_{2}$-eq (S5) to $465 \mathrm{~kg} \mathrm{CO}_{2}$-eq (S2). Figure $4 \mathrm{~b}$ shows the carbon footprint of a wooden bed under different imported timber origins. Since the carbon footprint of laminated lumber was far greater than that of sawn timber in the control case, the origins of the imported timber for producing laminated timber were considered, which included New Zealand (control case), Australia, Chile, South Africa, and Canada. It is noted that ocean transportation contributed the most to carbon emissions in the control case. While the origins of the imported timber was changed from New Zealand (control case) to Chile, the total carbon footprint increased by $11.4 \%$ (517 $\mathrm{kg} \mathrm{CO}_{2}$-eq), which indicated that the variation of imported timber origin had a considerable impact on the total carbon footprint. Figure 4c shows the carbon footprint of a wood bed under different domestic transportation distances. Currently, the transportation of timber and wooden furniture in China heavily depends on road transportation, which is a carbon-intensive transport mode. When the domestic transportation distance was changed from 400 to 800 $\mathrm{km}$, the total carbon footprint increased from $456 \mathrm{~kg}$ to $489 \mathrm{~kg} \mathrm{CO}_{2}$-eq. Figure $4 \mathrm{~d}$ shows the carbon footprint of a wood bed under different combinations of waste treatment modes. Even though waste treatment accounted for a small proportion of the total carbon footprint, the treatment of wasted furniture has received more attention recently. Compared to the control case of $60 \%$ for incineration and $40 \%$ for landfill dumping, an increase of incineration proportion to $90 \%$ will reduce the total carbon footprint to $471 \mathrm{~kg} \mathrm{CO}$-eq, 
while cutting down the incineration proportion to $50 \%$ will reduce the total carbon footprint by $0.5 \%$. In summary, the configuration of a timber harvesting system with less fuel consumption, purchasing timber from areas with shorter ocean transportation distances, and reducing the proportion of incineration for wood waste treatment are feasible solutions for reducing the life cycle carbon footprint of a solid wood bed that relies on imported timber.

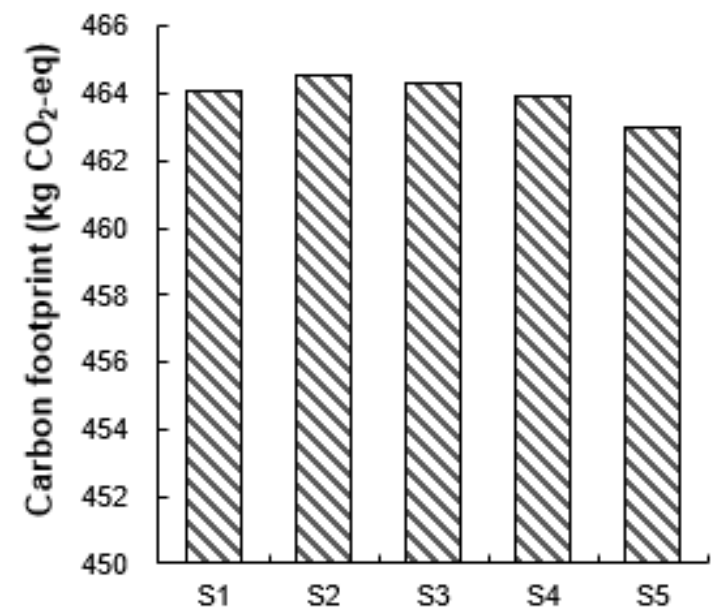

(a) Configurations of timber harvesting system

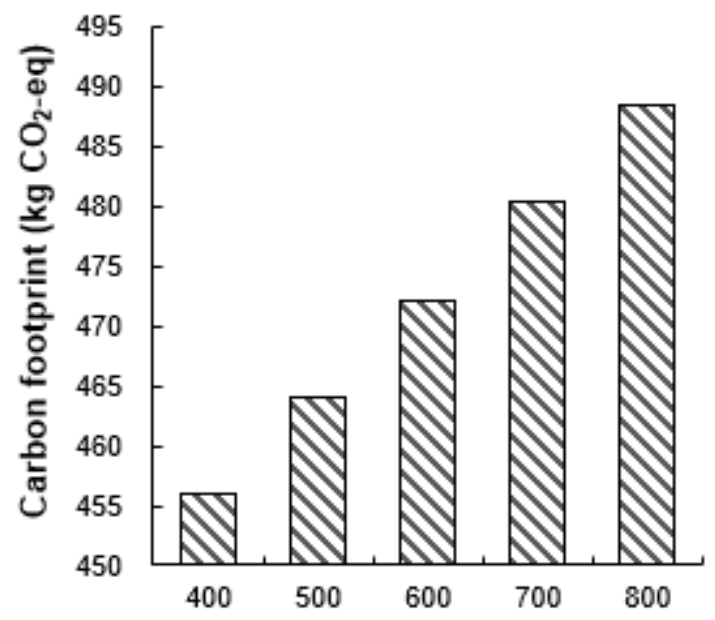

(c) Domestic road transportation distances

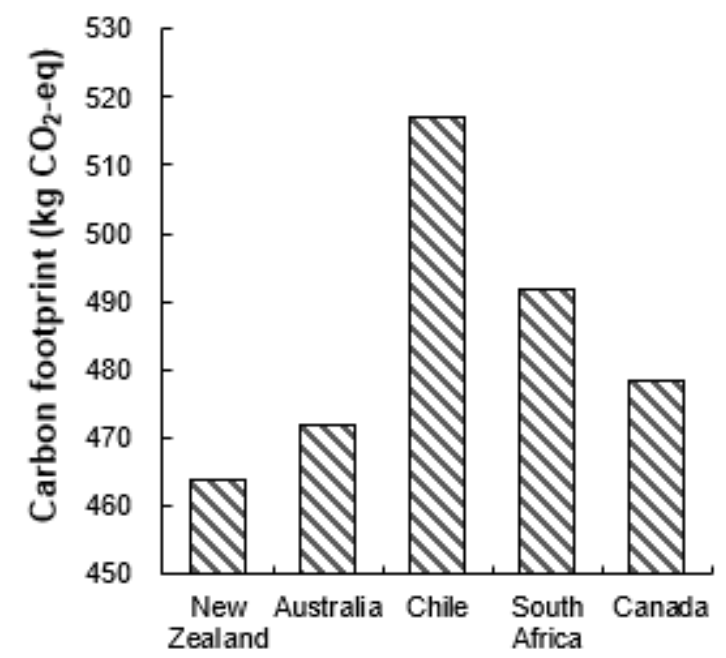

(b) Origins of imported timber

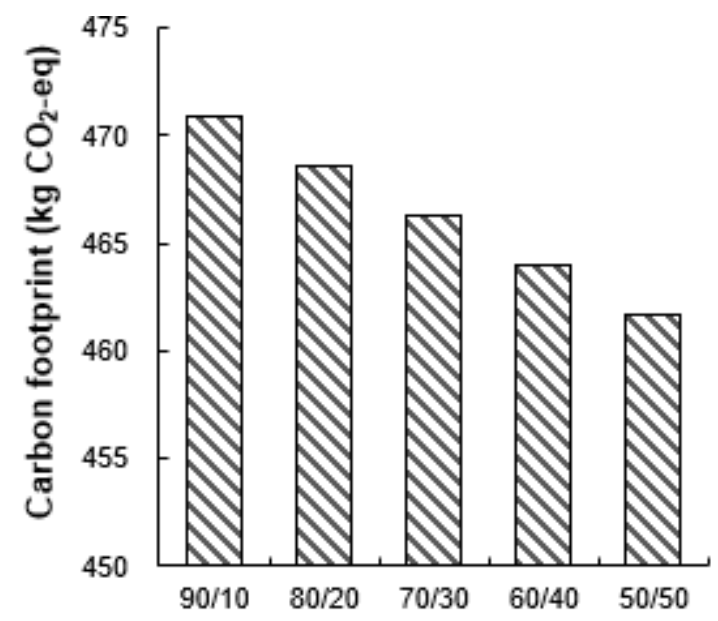

(d) Waste treatment (incineration/landfill)

Fig. 4. Carbon footprint of a functional unit solid wood bed in different scenarios

\section{Low-carbon Path Optimization}

The structure of the wooden furniture supply chain is extremely complex, and is composed of different suppliers, manufacture, retailers, users, and recycling agencies. In order to simplify the structure of the wooden furniture supply chain and focus on the carbon emission entities, several assumptions were made, as follows: (a) except for furniture manufacturers, only three typical enterprises were taken as representatives at each level of the supply chain; and (b) let $A_{i}$ represent suppliers $(i=1,2,3), B_{l}$ represent the core furniture manufacturer, $C_{j}$ represent distributors $(j=1,2,3), D_{k}$ represent retailers $(k=1,2,3)$, and $E_{n}$ represent recycling agencies $(n=1,2,3)$. The carbon footprint at node $A_{i}$ was based on the 
upstream processes in the control case. With other parameters remaining the same, different timber harvesting systems (S1, S3, S5), origins of the imported timber (New Zealand, Canada, Australia), and the domestic timber transportantion distances $(500 \mathrm{~km}$, $800 \mathrm{~km}, 1,000 \mathrm{~km}$ ) were combined to form $\mathrm{A}_{1}$ (S1, New Zealand, $\left.500 \mathrm{~km}\right), \mathrm{A}_{2}$ (S3, Canada, $800 \mathrm{~km})$, and $\mathrm{A}_{3}(\mathrm{~S} 5$, Australia, $1000 \mathrm{~km})$. The carbon footprint of the core-stream processes occurred at $B_{1}$; the carbon footprint of node $C_{j}$ was the carbon footprint of the first-level distribution in the downstream processes with different transportation distances $\left(\mathrm{C}_{1}\right.$ is $1000 \mathrm{~km}, \mathrm{C}_{2}$ is $1200 \mathrm{~km}$, and $\mathrm{C}_{3}$ is $800 \mathrm{~km}$ ). The carbon footprint of node $D_{k}$ was the carbon footprint of the second-level distribution with different transportation distances ( $\mathrm{D}_{1}$ is $40 \mathrm{~km}, \mathrm{D}_{2}$ is $50 \mathrm{~km}$, and $\mathrm{D}_{3}$ is $60 \mathrm{~km}$ ). The carbon footprint at node $E_{n}$ was the carbon footprint of waste recycling and treatment. Different recycling transportantion distances $(50 \mathrm{~km}, 55 \mathrm{~km}$, and $60 \mathrm{~km}$ ) and different ratios of incineration to landfill (60 to 40, 70 to 30 , and 80 to 20) were combined to form $\mathrm{E}_{1}$ (50 km and 60 to 40), $\mathrm{E}_{2}$ (55 km and 70 to 30), and $\mathrm{E}_{3}(60 \mathrm{~km}$ and 80 to 20$)$. The weighted directed graph of the wooden furniture supply chain is shown in Fig. 5.

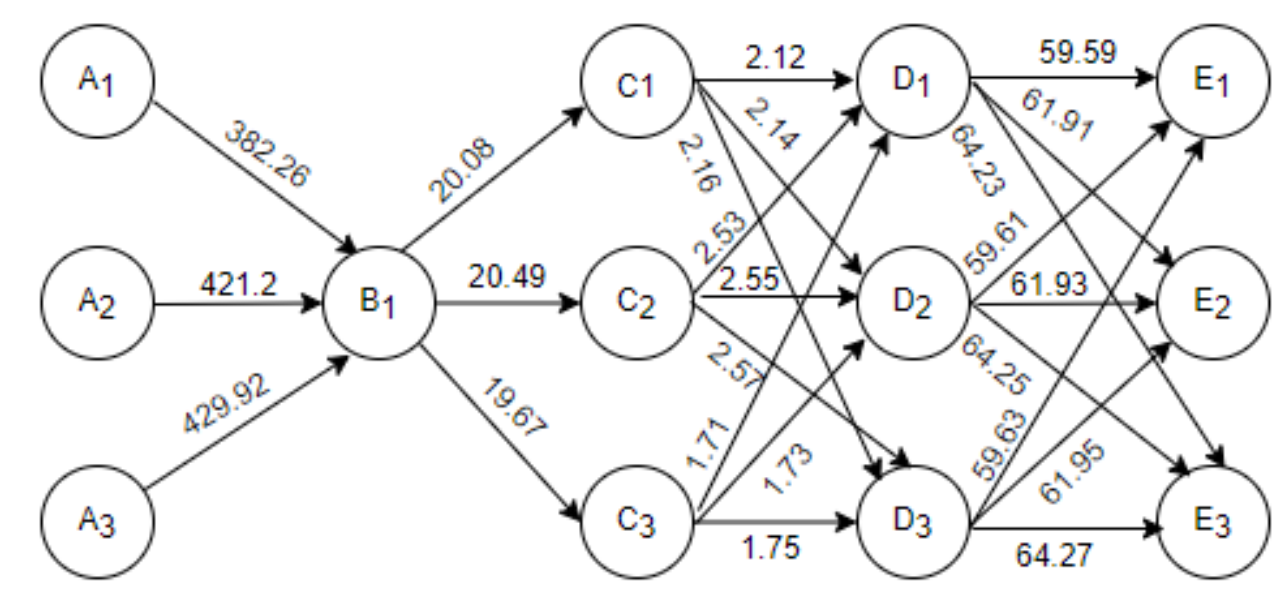

Fig. 5. Weighted directed graph of the wooden furniture supply chain

In order to reduce the traversal time, the Dijkstra algorithm was improved as follows: when selecting the next shortest path node, only the neighboring nodes, i.e., directly related to the upper-level node and located downstream of the source node in the direction of the supply chain, were considered, and then the value of the selected neighboring nodes was updated. Taking $A_{1}$ as the starting point, the results of the improved Dijkstra algorithm solution are shown in Table 4. The improved Dijkstra algorithm node path can be described as follows:

Step 1: Initialize $T=\{A\}$, establish a node set $N$ adjacent to $A$;

Step 2: If $d(A, N)=\min _{i \in N}\left(d\left(A, N_{i}\right)\right)$, then $T=T \cup N_{i}$;

Step 3: If all nodes are in $T$, the algorithm ends;

Step 4: For each node in $N-T$, update its length, and go back to step 2. 
Table 4. Results of the Improved Dijkstra Algorithm Solution

\begin{tabular}{|c|c|c|c|c|c|c|c|}
\hline $\begin{array}{l}\text { Repeat } \\
\text { Times }\end{array}$ & $\mathrm{T}$ & $x$ & A & B & C & D & $E$ \\
\hline Initialize & $\left(A_{1}\right)$ & $A_{1}$ & $\begin{array}{l}382.26 \\
\left(A_{1} B_{1}\right)\end{array}$ & & & & \\
\hline 1 & $\left(A_{1} B_{1}\right)$ & $\mathrm{B}_{1}$ & & & $\begin{array}{c}402.34 \\
402.75 \\
401.93 \\
\left(A_{1} B_{1} C_{1}\right) \\
\left(A_{1} B_{1} C_{2}\right) \\
\left(A_{1} B_{1} C_{3}\right)\end{array}$ & & \\
\hline 2 & $\left(\mathrm{~A}_{1} \mathrm{~B}_{1} \mathrm{C}_{1}\right)$ & $\mathrm{C}_{1}$ & & & & $\begin{array}{c}403.64 \\
403.66 \\
403.68 \\
\left(A_{1} B_{1} C_{3} D_{1}\right) \\
\left(A_{1} B_{1} C_{3} D_{2}\right) \\
\left(A_{1} B_{1} C_{3} D_{3}\right)\end{array}$ & \\
\hline 3 & $\left(A_{1} B_{1} C_{1} D_{1}\right)$ & $\mathrm{D}_{1}$ & & & & & $\begin{array}{c}463.23 \\
465.55 \\
467.87 \\
\left(A_{1} B_{1} C_{3} D_{1} E_{1}\right) \\
\left(A_{1} B_{1} C_{3} D_{1} E_{2}\right) \\
\left(A_{1} B_{1} C_{3} D_{1} E 3\right)\end{array}$ \\
\hline End & & & $\begin{array}{r}382.26 \\
\left(A_{1} B_{1}\right)\end{array}$ & & $\begin{array}{c}401.93 \\
\left(\mathrm{~A}_{1} \mathrm{~B}_{1} \mathrm{C}_{3}\right)\end{array}$ & $\begin{array}{c}403.64 \\
\left(\mathrm{~A}_{1} \mathrm{~B}_{1} \mathrm{C}_{3} \mathrm{D}_{1}\right)\end{array}$ & $\begin{array}{c}463.23 \\
\left(\mathrm{~A}_{1} \mathrm{~B}_{1} \mathrm{C}_{3} \mathrm{D}_{1} \mathrm{E}_{1}\right)\end{array}$ \\
\hline
\end{tabular}

It is shown in Table 4 that supplier $A_{1}$, furniture manufacturer $B_{1}$, distributor $C_{3}$, retailer $\mathrm{D}_{1}$, and recycling agency $\mathrm{E}_{1}$ was the shortest path in the graph and the minimum total carbon footprint of a solid wood box bed was $463 \mathrm{~kg} \mathrm{CO}_{2}$-eq. It should be noted that the conditions were strictly simplified in this study to search for the best path; the suppliers were only focused on $A_{1}, A_{2}$, and $A_{3}$ without taking into account the separate procurement of wood and other auxiliary materials, as well as multi-level suppliers for the processed semi-finished products. However, the network structure of an actual wooden furniture product supply chain was extremely complex due to the differences in product types, sources of raw materials, the channels of distribution, etc. The establishment of carbon emission evaluation indicators for different types of enterprises, e.g., suppliers, furniture manufacturers, distributors, retailers, and recycling agencies can ensure the accuracy of the weights of the wooden furniture product supply chain network system, which are the prerequisites for the optimal choice of low-carbon paths. In addition, only the carbon footprint was considered as the criterion for enterprise selection in this study without considering the other influencing factors such as economic factors and decision-makers' preferences. In fact, a process may not follow its absolute low-carbon path, especially when these may conflict with market dynamics and individual trading decisions. Both of the economic costs (i.e., procurement, production, distribution, recycling and waste treatment) and the environmental cost associated with carbon emissions should be considered when designing a supply chain network. In this study, there was only one manufacturing facility and the costs of main raw material Pinus radiata from different regions varied slightly, so the material cost (a part of procurement cost) and production cost were assumed to have 
less or no impact on the network structure. The other costs were mainly dominated by transportation costs, which were highly correlated with the carbon emission cost. Therefore, only the factor of carbon emissions was used in low-carbon path design. However, it is noted that the wooden furniture supply chain involved multiple independent participants; each participant can contribute to a low-carbon product by using environmentally friendly materials, improving manufacturing technology, selecting efficient transport modes, using cleaner fuel, or conducting post-use material reclamation (Medeiros et al. 2017). In addition, information and communications technology (ICT) currently permeates the economic, social, and environmental dimensions of many nations around the world, which will allow more reasonable logistical paths of production to be developed (Hong et al. 2018). As the core enterprise of a supply chain, a company that owns multiple production facilities can expand their internal greening activities through vertical and horizontal integration with their upstream and downstream stakeholders. Future research can be conducted to analyze the coordination mechanism of the complicated wooden furniture supply chain by combining the economic, environmental, and social incentives in order to increase the competitiveness of the supply chain and promote the sustainable development of wooden furniture products.

\section{CONCLUSIONS}

1. The life cycle carbon footprint of an imported timber-based solid wood box bed (2000 $\mathrm{mm} \times 1800 \mathrm{~mm}$ ) was calculated to be $464 \mathrm{~kg} \mathrm{CO}$-eq for the control case. However, there were considerable uncertainties in certain links in the wooden furniture supply chain in terms of the carbon footprint. Under the constraints of different timber harvesting systems, the origins of the imported timber, domestic transportation distances, and waste treatment modes, the carbon footprint of the studied solid wood box bed ranged from 456 to $517 \mathrm{~kg} \mathrm{CO}_{2}$-eq.

2. The upstream processes were the major contributors to the carbon footprint of a solid wood bed, which accounted for $74.6 \%$ to $80.7 \%$ of the total carbon footprint in various cases. Therefore, reducing the carbon emissions in the upstream processes, especially choosing a reasonable transportation route, improving the processing technology for laminated timber production, and reducing the usage of paint, can effectively reduce the life cycle carbon footprint of wooden furniture products.

3. In terms of optimizing the low-carbon path of a wooden furniture supply chain, it is necessary not only to reduce the carbon emissions of different types of enterprises, e.g., suppliers, furniture manufacturers, retailers, distributors, and recycling agencies, but also to promote green cooperation among different enterprises. Therefore, environmental, economic, social, and other factors should be considered and a cooperation mechanism for sharing the profits and carbon reduction costs should be established for different stakeholders in the wooden furniture supply chain in order to achieve the low carbon targets.

Wang et al. (2021). "Wooden furniture carbon footprint," BioResources 16(4), 6870-6890. 6886 


\section{ACKNOWLEDGEMENTS}

The authors would like to acknowledge the support of Natural Science Foundation of Heilongjiang Province, China (LH2021G001).

\section{REFERENCES CITED}

Abdallah, T., Farhat, A., Diabat, A., and Kennedy, S. (2012). "Green supply chains with carbon trading and environmental sourcing: formulation and life cycle assessment," Applied Mathematical Modelling 36(9), 4271-4285. DOI:10.1016/j.apm.2011.11.056

Akhtari, S., Sowlati, T., Siller-Benitez, D.G., and Roeser, D. (2019). "Impact of inventory management on demand fulfilment, cost and emission of forest-based biomass supply chains using simulation modelling," Biosystems Engineering 178, 184-199. DOI: 10.1016/j.biosystemseng.2018.11.015

Ali, S. S., Kaur, R., Persis, D. J., Saha, R., Pattusamy, M., and Sreedharan, V. (2020). "Developing a hybrid evaluation approach for the low carbon performance on sustainable manufacturing environment," Annals of Operations Research 1-33. DOI: 10.1007/s10479-020-03877-1

Anil, S. K. (2010). Environmental Analysis of Pallets Using Life Cycle Analysis and Multi-Objective Dynamic Programming, Master's Thesis, Penn State University, State College, PA.

Anil, S. K., Ma, J., Kremer, G. E., Ray, C. D., and Shahidi, S. M. (2020). "Life cycle assessment comparison of wooden and plastic pallets in the grocery industry," Journal of Industrial Ecology 24(4), 871-886. DOI: 10.1111/jiec.12974

Athanassiadis, D., Lidestav, G., and Wästerlund, I. (1999). "Fuel, hydraulic oil and lubricant consumption in Swedish mechanized harvesting operations, 1996," International Journal of Forest Engineering 10, 59-66. DOI: 10.1080/08435243.1999.10702725

AzariJafari, H., Yahia, A., and Amor, M. B. (2016). "Life cycle assessment of pavements: reviewing research challenges and opportunities," Journal of Cleaner Production 112(4), 2187-2197. DOI: 10.1016/J.JCLEPRO.2015.09.080

Bai, W. R., Wang, Z., and Jing, Y. Q. (2013). "Carbon footprint accounting of wooden furniture based on life cycle assessment method," Chinese Journal of Wood Science and Technology 27(6), 29-32, 36. DOI: 10.19455/j.mcgy.2013.06.007

Bai, W. R., Wang, Z., and Lü, J. (2014). "Summary and analysis of international standards on carbon footprint accounting," Acta Ecologica Sinica 32(24), 7486-7493. DOI: $10.5846 /$ stxb201303120405

Brinker, R. W., Kinard, J., Rummer, B., and Lanford, B. (2002). Machine Rates for Selected Forest Harvesting Machines, Alabama Agricultural Experiment Station, Auburn, Alabama.

Chen, C. X., Pierobon, F., and Ganguly, I. (2019). "Life cycle assessment (LCA) of cross-laminated timber (CLT) produced in western Washington: The role of logistics and wood species mix," Sustainability 11(5), 1-17. DOI: 10.3390/SU11051278

Dai, Q., Hu, J. H, Ji, X. D., and Guo, M. H. (2018). "Environmental efficiency effect of building glulam manufacturing technology," Journal of Forestry Engineering 3(4), 46-50. DOI: 10.13360/j.issn.2096-1359.2018.04.008 
Dong, Y., Xia, B., and Chen, W. (2014). "Carbon footprint of urban areas: An analysis based on emission sources account model," Environmental Science \& Policy 44, 181189. DOI: 10.1016/J.ENVSCI.2014.07.013

Garcia, R., and Freire, F. (2014). "Carbon footprint of particleboard: a comparison between ISO/TS 14067, GHG protocol, PAS 2050 and climate declaration," Journal of Cleaner Production 66, 199-209. DOI: 10.1016/J.JCLEPRO.2013.11.073

Garcia, R., and Freire, F. (2011). "Comparative assessment of environmental life-cyclebased tools: An application to particleboard," in: Proceedings of the 2011 IEEE International Symposium on Sustainable Systems and Technology, 16-18 May, Chicago, IL, pp. 1-1.

Garofalo, P., D'Andrea, L., Tomaiuolo, M., Venezia, A., and Castrignanò, A. (2017). "Environmental sustainability of agri-food supply chains in Italy: The case of the whole-peeled tomato production under life cycle assessment methodology," Journal of Food Engineering 200, 1-12. DOI: 10.1016/J.JFOODENG.2016.12.007

GHG Protocol (2011). "Product life cycle accounting and reporting standard," World Resources Institute and World Business Council for Sustainable Development, Washington DC, USA and Geneva, Switzerland.

Ghaffariyan, M. R., Brown, M., and Acuna, M. (2012). "Cut-to-length harvesting system evaluation in Southern Tasmania, Australia," in: Proceedings of the $45^{\text {th }}$ International Symposium on Forestry Mechanization, 8-12 October, Dubrovnik, Croatia.

Gierling, F., and Blanke, M. (2021). "Carbon reduction strategies for regionally produced and consumed wine: From farm to fork," Journal of Environmental Management 278 (1), article no. 111453. DOI: 10.1016/j.jenvman.2020.111453

González-García, S., Gasol, C. M., Lozano, R. G., Moreira, M. T., Gabarrell, X., Pons, J. R. i, and Feijoo, G. (2011). "Assessing the global warming potential of wooden products from the furniture sector to improve their eco-design," The Science of the Total Environment 410-411, 16-25. DOI: 10.1016/j.scitotenv.2011.09.059

González-García, S., Lozano, R. G., Moreira, M. T., Gabarrell, X., Pons, J. R. i, Feijoo, G., and Murphy, R. (2012). "Eco-innovation of a wooden childhood furniture set: an example of environmental solutions in the wood sector," The Science of the Total Environment 426, 318-26. DOI:10.1016/j.scitotenv.2012.03.077.

Guo, L. (2017). The Research on Product Carbon Footprint Data Acquisition and Application under the Environment of Supply Chain, Master's Thesis, Zhejiang SciTech University, Hangzhou, China.

Hawkins, J., Weersink, A., Wagner-Riddle, C., and Fox, G. (2015). “Optimizing ration formulation as a strategy for greenhouse gas mitigation in intensive dairy production systems," Agricultural Systems 137, 1-11. DOI:10.1016/J.AGSY.2015.03.007

He, X. (2016). "Research on transportation mode in supply chain based on carbon footprint," Logistics Sci-Tech 16(9), 77-80. DOI: 10.13714/j.cnki.10023100.2016.09.020

Healey, S. P., Blackard, J. A., Morgan, T. A., Loeffler, D., Jones, G., Songster, J. P., Brandt, J. P., Moisen, G., and DeBlander, L. T. (2009). "Changes in timber haul emissions in the context of shifting forest management and infrastructure," Carbon Balance and Management 4, 1-11. DOI: 10.1186/1750-0680-4-9

Hong, I. H., Su, J., Chu, C. H., and Yen, C. Y. (2018). "Decentralized decision framework to coordinate product design and supply chain decisions: evaluating tradeoffs between cost and carbon emission, "Journal of Cleaner Production 204, 107-116. DOI:10.1016/j.jclepro.2018.08.239

Wang et al. (2021). "Wooden furniture carbon footprint," BioResources 16(4), 6870-6890. 6888 
ISO 14040 (2006) "Environmental management_life cycle assessment_principles and framework. International Organization for Standardization, Geneva, Switzerland.

ISO 14067 (2018). “Greenhouse gases - Carbon footprint of products - Requirements and guidelines for quantification," International Organization for Standardization, Geneva, Switzerland.

Javaid, A. (2013). “Understanding Dijkstra's algorithm," SSRN Electronic Journal 1-27. DOI: $10.2139 / \mathrm{ssrn} .2340905$

Kulak, M., Nemecek, T., Frossard, E., and Gaillard, G. (2016). "Eco-efficiency improvement by using integrative design and life cycle assessment: The case study of alternative bread supply chains in France," Journal of Cleaner Production 112(Part 4), 2452-2461. DOI: 10.1016/J.JCLEPRO.2015.11.002

Kwangsawat, K., and Rugwongwan, Y. (2017). "The different analysis of carbon footprint according to life cycle assessment of furniture type: A case study of the table," Environment-Behaviour Proceedings Journal 2(5), 315-323. DOI:10.21834/EBPJ.V2I5.654

Ledgard, S. F., Falconer, S. J., Abercrombie, R., Philip, G., and Hill, J. P. (2020). "Temporal, spatial, and management variability in the carbon footprint of New Zealand milk," J. Dairy Science 103(1), 1031-1046. DOI: 10.3168/jds.2019-17182

Li, B. (2011). Study on the Carbon Emission of Agricultural Land Utilization and Emission-Reducted Policy in China, Ph.D. Dissertation, Huazhong Agricultural University, Wuhan, China.

Lijewski, P., Merkisz, J., Fuć, P., Ziólkowski, A., Rymaniak, Ł., and Kusiak, W. (2016). "Fuel consumption and exhaust emissions in the process of mechanized timber extraction and transport," European Journal of Forest Research 136, 153-160. DOI: $10.1007 / \mathrm{s} 10342-016-1015-2$

Lin, L., and Huang, S. (2016). "Carbon footprint assessment of wood-based product," Journal of Central South University of Forestry \& Technology 36(12), 135-139. DOI: 10.14067/j.cnki.1673-923x.2016.12.023

Lin, W., Wang, J., Wu, J., and DeVallance, D. (2011). "Log sawing practices and lumber recovery of small hardwood sawmills in West Virginia," Forest Products Journal 61(3), 216-224. DOI: 10.13073/0015-7473-61.3.216

Linkosalmi, L., Husgafvel, R., Fomkin, A., Junnikkala, H., Witikkala, T., Kairi, M., and Dahl, O. (2016). "Main factors influencing greenhouse gas emissions of wood-based furniture industry in Finland," Journal of Cleaner Production 113, 596-605. DOI: 10.1016/J.JCLEPRO.2015.11.091

Liu, Y., and Wang Z. (2016). "Effects of different import patterns on the carbon footprint of Chinese export products: A case study on wooden cabinet," Acta Scientiae Circumstantiae 36(2), 710-716. DOI: 10.13671/j.hjkxxb.2015.0457

Mantyka-Pringle, C. S., Visconti, P., Marco, M. D., Martin, T. G., Rondinini, C., and Rhodes, J. R. (2015). "Climate change modifies risk of global biodiversity loss due to land-cover change,” Biological Conservation 187, 103-111. DOI: 10.1016/J.BIOCON.2015.04.016

Medeiros, D. L., Tavares, A. O. d. C., Rapôso, Á. L. Q. R. e S., and Kiperstok, A. (2017). "Life cycle assessment in the furniture industry: The case study of an office cabinet," The International Journal of Life Cycle Assessment 22, 1823-1836._DOI: 10.1007/s11367-017-1370-3

Mota, B., Gomes, M. I., Carvalho, A., and Barbosa-Povoa, A. (2015). "Towards supply chain sustainability: Economic, environmental and social design and planning," 
Journal of Cleaner Production 105, 14-27. DOI:10.1016/j.jclepro.2014.07.052

National Development and Reform Commission of China. "2012 Baseline Emission Factors for Regional Power Grids in China," (https://www.ndrc.gov.cn), Accessed January 3, 2021.

Ness, B., Urbel-Piirsalu, E., Anderberg, S., and Olsson, L. (2007). "Categorising tools for sustainability assessment," Ecological Economics 60, 498-508. DOI: 10.1016/j.ecolecon.2006.07.023

Nieuwlaar, E. (2004). "Life cycle assessment and energy systems," Encyclopedia of Energy 29(3), 647-654. DOI: 10.1016/B978-0-12-409548-9.01334-8

Pandey, D., Agrawal, M., and Pandey, J. S. (2011). "Carbon footprint: Current methods of estimation," Environmental Monitoring and Assessment 178, 135-160. DOI: $10.1007 / \mathrm{s} 10661-010-1678-\mathrm{y}$

PAS 2050 (2011). "Specification for the assessment of the life cycle greenhouse gas emissions of goods and services," British Standards Institution, London, UK.

Popovici, R. (2013). "Estimating chainsaw operating costs based on fuel, lubricants and spare parts," Bulletin of the Transilvania University of Brasov 6(55), 63-68.

Shen, J. Wu, J., and Lin, W. (2014). "Life cycle impact assessment and its application of sawn timber product," Journal of Northeast Forestry University 42(10), 135-140. DOI: 10.13759/j.cnki.dlxb.20140721.029

Sunita, and Garg, D. (2021). "Dynamizing Dijkstra: A solution to dynamic shortest path problem through retroactive priority queue," Journal of King Saud University Computer and Information Science 33(3), 364-373. DOI: 10.1016/J.JKSUCI.2018.03.003

Tellnes, L. G. F., Alfredsen, G., Flæte, P. O., and Gobakken, L. (2019). "Effect of service life aspects on carbon footprint: A comparison of wood decking products," Holzforschung 74(4), 426-433. DOI: 10.1515/hf-2019-0055

United Nations (2021). "UN comtrade database," (https://comtrade.un.org), Accessed March 8, 2021.

Wang, H., Wang, P., and Liu, X. (2019). "Railway emergency material allocation scheme based on Dijkstra algorithm," Railway Computer Applications 28(10), 1-4.

Wang, J., Long, C., McNeel, J., and Baumgras, J. (2004). "Productivity and cost of manual felling and cable skidding in central Appalachian hardwood forests," Forest Products Journal 54(12), 45-51.

Wang, S., and Li, A. (2014). "Multi-adjacent-vertexes and multi-shortest-paths problem of Dijkstra algorithm," Computer Science 41(6), 217-224.

Xie, T., and Wang, J. (2011). "Comparative research on carbon emissions of transportation industry," Comprehensive Transportation 18(8), 20-24.

Yin, J., and Liu, J. (2014). "Research on low-carbon paths of automotive supply chain," Ecological Economy 30(11), 57-60.

Yu, H., Tian, M., Shi, Y., Cheng, J., and Zhang, Z. (2018). "The measuring methods of dependence on foreign trade of China's wooden forest products and the estimating after measuring," Scientia Silvae Sinicae 54(5), 152-167. DOI: 10.11707/j.10017488.20180517

Article submitted: May 8, 2021; Peer review completed: July 8, 2021; Revised version accepted July 26, 2021; Published: August 27, 2021.

DOI: 10.15376/biores.16.4.6870-6890 